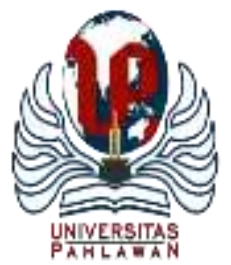

Edukatif : Jurnal Ilmu Pendidikan Volume 3 Nomor 6 Tahun 2021 Halm 3828 - 3838

EDUKATIF: JURNAL ILMU PENDIDIKAN

Research \& Learning in Education

https://edukatif.org/index.php/edukatif/index

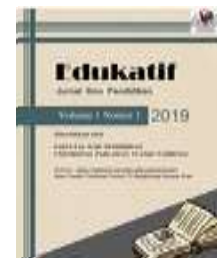

\title{
Kajian Morfologis pada Pemberitaan Habib Rizieq Shihab Rekomendasinya sebagai Materi Menyusun Teks Berita Di SMP
}

\author{
Mia Solihat $^{1 \otimes}$, Hendra Setiawan ${ }^{2}$, Ferina Meliasanti ${ }^{3}$ \\ Universitas Singaperbangsa Karawang, Indonesia ${ }^{1,2,3}$ \\ E-mail : $\underline{\text { solihatmia70@gmail.com }}{ }^{1}, \underline{\text { hendra.setiawan@ fkip.unsika.ac.id }}^{2}, \underline{\text { ferina.meliasanti@ fkip.unsika.ac.id }}^{3}$
}

\begin{abstract}
Abstrak
Penelitian ini bertujuan untuk mendeskripsikan kajian morfologis berupa afiksasi, reduplikasi, dan komposisi pada pemberitaan Habib Rizieq Shihab dalam media detiknews.com edisi Mei 2021 yang direkomendasikan sebagai materi menyusun teks berita di sekolah menengah pertama kelas VIII. Metode yang digunakannya yaitu menggunakan metode deskriptif kualitatif dengan tenik pengumpulan datanya yaitu menggunakan teknik dokumentasi, simak, dan catat. Hasil dari penelitian ini yaitu menunjukkan bahwa di dalam 13 berita yang telah dianalisis terdapat 36 data kesalahan dalam proses morfologis afiksasi, reduplikasi, dan pemajemukan, dengan rincian yaitu terdapat 3 kesalahan dalam bidang afiksasi, 2 kesalahan dalam bidang reduplikasi, dan 2 kesalahan dalam bidang pemajemukan. Hasil dari penelitian ini dapat direkomendasikan sebagai materi menyusun teks berita di SMP Kelas VIII semester ganjil sesuai dengan kompetensi dasar 4.2 menyajikan data dan informasi dalam bentuk berita secara lisan dan tulis dengan memperhatikan struktur, kebahasaan, atau aspek lisan (lafal, intonasi, mimik, dan kinesik) yang terdapat di dalam silabus dengan indikator yaitu menyusun teks berita berdasarkan data-data yang telah disusunnya.
\end{abstract}

Kata Kunci : Kajian morfologis, pemberitaan habib rizieq shihab, teks berita.

\section{Abstract}

This study aims to describe morphological studies in the form of affixation, reduplication, and composition on the news of Habib Rizieq Shihab in May 2021 edition of detiknews.com media which is recommended as material for compiling news texts in grade VIII junior high school. The method used is descriptive qualitative method with data collection techniques, namely using documentation, listening, and note-taking techniques. The result of this study indicates that in 13 news stories that have been analyzed there are 36 data errors in the morphological process of affixation, reduplication, and compounding, with details that there are 3 errors in the affixation field, 2 errors in the reduplication field, and 2 errors in the compounding field. The results of this study can be recommended as material for compiling news texts in SMP Class VIII odd semesters in accordance with basic competence 4.2 presenting data and information in the form of news orally and writing by paying attention to structure, language, or oral aspects (pronunciation, intonation, expression, and expression kinesics) contained in the syllabus with indicators, namely compiling news texts based on the data they have compiled.

Keywords: Morphological study, habib rizieq shihab news, news text.

Copyright (c) 2021 Mia Solihat, Hendra Setiawan, Ferina Meliasanti

$\triangle$ Corresponding author

Email : solihatmia70@gmail.com

DOI : https://doi.org/10.31004/edukatif.v3i6.1259

ISSN 2656-8063 (Media Cetak)

ISSN 2656-8071 (Media Online)

Edukatif : Jurnal Ilmu Pendidikan Vol 3 No 6 Tahun 2021

p-ISSN 2656-8063 e-ISSN 2656-8071 
3829 Kajian Morfologis pada Pemberitaan Habib Rizieq Shihab Rekomendasinya sebagai Materi Menyusun Teks Berita Di SMP - Mia Solihat, Hendra Setiawan, Ferina Meliasanti

DOI: https://doi.org/10.31004/edukatif.v3i6.1259

\section{PENDAHULUAN}

Bahasa yaitu sebagai alat komunikasi yang dipakai manusia di dalam kehidupannya, guna untuk memberikan informasi atau gagasan terhadap masyarakat. Bahasa tidak hanya sekadar alat untuk berkomunikasi saja yang digunakan manusia dalam kehidupan bermasyarakat, tetapi bahasa juga bisa digunakan manusia untuk menyatakan perasaan dan menyatakan pendapat atau gagasan pokok. Selain itu, bahasa juga dapat dikatakan sebagai sistem lambang bunyi yang arbitrer, dimana bahasa tersebut dapat dipergunakan oleh manusia guna saling berinteraksi, bekerjasama, saling komunikasi atau bercakap- cakapan dengan baik sehingga menimbulkan tingkah laku yang baik dan sopan, (KBBI V, 2018). Oleh sebab itu, bahasa dijadikan sebagai media komunikasi yaitu untuk mengungkapkan pendapat.

Bahasa tidak hanya sekadar alat komunikasi lisan saja, tetapi bahasa juga dapat dijadikan sebagai alat komunikasi yang cara penyampaiannya secara tidak langsung kepada pembaca yaitu dengan melalui tulisan. Bahasa tulisan dapat dilakukan dengan kegiatan menulis, karena menulis sebagai suatu keterampilan bahasa berupa catatan yang dipergunakan manusia untuk saling berkomunikasi, serta sebagai kegiatan untuk menuangkan gagasannya terhadap apa yang ada di dalam pikirannya lalu dituangkan dalam bentuk tulisan guna untuk saling komunikasi dengan masyarakat dengan cara tidak langsung, (Tarigan, 2013). Oleh karena itu, bahasa tulis dengan kegiatan menulis saling berhubungan antara satu sama lain.

Media komunikasi yang digunakan oleh manusia untuk saling berkomunikasi yaitu ada dua jenis diantaranya media komunikasi cetak dan media komunikasi non cetak. Media komunikasi cetak yaitu seperti koran, majalah, dan tabloid. Sedangkan media komunikasi non cetak yaitu seperti radio, televisi, handphone, dan internet. Berdasarkan dari penjelasan tersebut, media komunikasi yang paling mudah digunakan serta informasinya paling cepat tersebar dan mudah diterima oleh masyarakat pada masa dahulu yaitu media komunikasi cetak koran. Tetapi dengan seiring perkembangan zaman, media komunikasi teknologi yang berkembang dengan begitu pesat, yaitu internet. Karena informasinya lebih cepat tersampaikan dibanding media komunikasi cetak koran. Dengan adanya media tersebut, tentu media komunikasi cetak koran semakin tergeser dan bahkan hampir punah. Bahkan media komunikasi yang paling banyak digunakan oleh manusia untuk saling berkomunikasi di zaman sekarang yaitu media internet.

Penulisan dalam karya tulis, tentu tidak sembaran asal menulis. Tetapi dalam penulisannya tentu harus memperhatikan serta mengikuti aturan kaidah bahasa Indonesia. Kaidah bahasa Indonesia yaitu mencakup penulisan ejaan, kosa kata, serta kalimat dan paragfar yang tersusun secara sistematis. Tujuan dari adanya aturan dan kaidah kebahasaan tersebut yaitu guna untuk penulisan karya ilmiah yang baik. Karena jika karya tulis tersebut tersususun dengan baik dan sudah sesuai aturan, maka tidak adanya kesalahan dalam penulisan. Tetapi, apabila di dalam penulisan karya tulis tidak mengikuti aturan yang telah ada dan tidak sesuai dengan kaidah bahasa Indonesia, maka akan terjadi kesalahan bahkan bisa juga berdampak dalam pengartian kata. Oleh karena itu, perlu adanya wawasan dan pemahaman terhadap kaidah bahasa Indonesia guna untuk tidak lagi terdapat kesalahan penulisan karya tulis.

Kesalahan berbahasa pada penulisan karya tulis ditemukan pada berita yang terdapat di media online. Berita yaitu informasi yang didapatkan oleh jurnalistik kemudian ditulis dalam media online guna untuk komunikasi menyampaikan informasi kepada masyarakat tentang peristiwa yang terjadi di masyarakat, Wirnani dan Rani (dalam Aulia \& Anggraini, 2020). Berkaitan dengan hal tersebut, bahwa berita merupakan kebutuhan publik guna untuk mengetahui berbagai macam informasi yang terdapat di dalam masyarakat. Oleh karena itu, perlu adanya wawasan yang lebih luas serta mengetahui aturan kaidah bahasa Indonesia guna untuk tidak terdapat lagi kesalahan. Selain itu, dalam penulisan berita tentu harus penulisannya harus mudah di pahami, dan menarik minat pembaca, tidak terlalu berbelit-belit sehingga pembaca mudah 
memahaminya, dan tidak kebingungan pada saat membacanya. Setelah dianalisis, kesalahan penulisan berita tidak hanya terdapat pada ejaan saja, tetapi terdapat juga kesalahan dalam bidang proses morfologis.

Proses morfologis yaitu suatu cara yang dilakukan untuk membentuk kata yang satu dengan kata yang lainnya dimana kata tersebut hanya bentuk kata dasar kemudian digabungkan dengan proses menggabungkan morfem sehingga kata yang telah dihubungkan dapat menimbulkan kata yang baru, dan yang menjadi bentuk terkecilnya dinamakan dengan morfem, sedangkan untuk bentuk terbesarnya yaitu dinamakan dengan kata, (Rohmadi et al., 2012: 39). Selain itu, di dalam proses morfologis terdapat tiga macam jenis, diantaranya 1) afiksasi / pengimbuhan kata, 2) reduplikasi / pengulangan kata, dan 3) pemajemukan/komposistum (Rohmadi et al., 2012: 40-41). Afiksasi yaitu proses pengubahan kata dasar menjadi kata yang lebih kompleks, (Kridalaksana, 2007). Sedangkan reduplikasi yaitu proses pengulangan kata dimana proses pengulangan tersebut dapat berubah dari kata dasar menjadi kata kompleks, (Damayanti \& Nugraheni, 2020), dan komposisi sebagai proses penggabungan kata dimana kata tersebut dapat menghasilkan berbagai macam bentuk kata majemuk, (Oktaviani \& Nasucha, 2016).

Berkaitan dengan permasalahan di atas, oleh karena itu penelitian ini akan meneliti berita yang ada di media online yaitu berita tentang Habib Rizieq Shihab dalam media detiknews.com edisi Mei 2021 serta penulisan dalam proses morfologis. Alasan peneliti mengambil penelitian tersebut karena setelah membaca berita tentang Habib Rizieq Shihab 2021, ternyata masih terdapat kesalahan penggunaan bahasa Indonesia khususnya pada tataran morfologis sehingga penulis merasa tertarik untuk menelitinya. Selain itu, jarang sekali yang menganalisis proses morfologis terutama dalam teks berita. Bahkan kebanyakan yang menganalisis proses morfologis tersebut dalam karangan-karangan siswa di sekolah. Dengan adanya penelitian ini, diharapkan dapat mengurangi kesalahan penulisan proses morfologis yang dilakukan dalam pembuatan teks berita terutama di media online.

Sehubungan dengan penelitian tersebut, penelitian ini pernah dilakukan oleh (Purwanto, 2016) dengan judul "Analisis Proses Morfologis Pada Kolom Sepak Bola di Koran Harian Solopos Edisi November 2014", (Isfanti \& Nasucha, 2017) dengan judul "Proses Morfologis dalam Rubrik Opini pada Surat Kabar Kompas Edisi Jumat, 26 Desember 2014 Sebagai Pembelajaran Bahasa Indonesia SMA/SMK/MA Kelas XII", (Rahmah, n.d.) dengan judul "Penggunaan Prefiks Pada Berita Detik.news di Media Daring Detik.com dan Implikasinya Terhadap Pembelajaran Bahasa dan Sastra Indonesia Kelas VIII SMP”, (Utami et al., 2021) dengan judul "Analisis Kesalahan Morfologi Kata Pada Laman Berita Daring Publikasi Online.id”, (Aprilia et al., 2020) dengan judul "Analisis Kesalahan Berbahasa Bidang Morfologi Pada Portal Radar Solo Tema Covid 19”, dan (Evitasari \& Nasucha, 2016) dengan judul "Kata Bersufiks pada Tajuk Rencana Suara Merdeka dan Implikasinya Terhadap Pembelajaran".

Berkaitan dengan pernyataan di atas, maka dapat dirumuskan dengan judul sebagai berikut "Kajian Morfologis pada Pemberitaan Habib Rizieq Shihab Terkait Kasus Kerumunan dan Rs Ummi Bogor dalam Detiknews.com Edisi Mei 2021 dan Rekomendasinya Sebagai Materi Menyusun Teks Berita Di Sekolah Menengah Pertama Kelas VIII'. Oleh sebab itu, hasil penelitian ini nantinya akan dijadikan sebagai materi menyusun teks berita di SMP Kelas VIII. Karena penelitian ini berkaitan dengan silabus KD 4.2 yaitu menyajikan data dan informasi dalam bentuk berita secara lisan maupun tulisan dengan memperhatikan struktur, kebahasaan, atau aspek lisan (lafal, intonasi, mimik,dan kinesik.

\section{METODE PENELITIAN}

Penelitian ini penulis menggunakan metode deskriptif kualitatif dan pendekatannya yaitu menggunakan pendekatan kualitatif. Metode penelitian kualitatif deskriptif tentu akan menghasilkan penjabaran hasil penelitian berupa kata-kata tetulis dimana hal tersebut dilakukan yaitu dengan proses 
mengumpulkan data-data terlebih dahulu kemudian data tersebut disusun, setelah itu diolah, kemudian dianalisis untuk mendapatkan gambaran mengenai penjelasan terhadap pemasalahan yang telah dikaji, Moleong (dalam Kristi, 2016). Subjek dalam penelitian ini yaitu berita Habib Rizieq Shihab terkait kasus kerumunan dan RS Ummi Bogor edisi Mei 2021 yang terdapat dalam media online Detiknews.com. Sedangkan objeknya yaitu kajian morfologis.

Teknik pengumpulan data yang digunakan dalam penelitian ini yaitu teknik dokumentasi, teknik simak dan teknik catat. Teknik dokumentasi yaitu berupa catatan-catatan peristiwa, dimana catatan tersebut berupa catatan peristiwa sudah berlalu dapat berupa tulisan, gambar, atau karya dari hasil seseorang untuk mendukung penelitian ini, (Sugiyono, 2018). Teknik ini digunakan dalam penelitian yaitu untuk mengumpulkan data-data tersebut dianalisis oleh penulis. Selanjutnya yaitu teknik simak, dimana teknik ini dapat dikatakan dengan metode simak atau dapat juga dikatakan dengan penyimakan, karena dalam teknik ini digunakan untuk berupa menyimak penggunaan bahasa terhadap subjek yang akan diteliti (Sudaryanto, 2015). Terakhir yaitu teknik catat dimana teknik ini mencatat data yang terdapat pada tabel dengan alat tulis atau instrumen penelitian untuk memudahkan pengamatan, teknik catat dapat dilakukan dengan cara langsung ketika teknik pertama atau kedua selesai digunakan atau diterapkan dengan menggunakan alat tulis tertentu, (Sudaryanto, 2015).

Instrumen yang digunakan pada penelitian ini adalah peneliti sendiri (human instrument), karena penelitiannya yaitu berupa kualitatif dimana data yang dianalisis hasilnya berupa penjabaran kata dalam bentuk tulisan dan bukan berupa angka. Oleh karena itu dalam penelitian ini memfokuskan pada kajian penelitian objek dan subjek dimana data-datanya mencari dan menganalisis sendiri.

Adapun teknik analisis data yang digunakan terhadap penelitian ini yaitu menggunakan metode agih. metode agih dapat menjadi alat penentu secara tepat terhadap dalam bahasa itu sendiri, (Sudaryanto, 2015). Di dalam metode agih terdapat teknik dasar atau disebut dengan teknik Bagi Unsur Langsung (BUL), (Sudaryanto, 2015). Tetapi di dalam teknik BUL terdapat juga teknik lanjutan. Teknik lanjutan yang digunakan oleh peneliti adalah teknik ganti. Dimana teknik ganti yaitu untuk mengetahui terdapat kesamaan makna atau tidaknya terhadap kata yang satu dengan kata yang lainnya yang sudah tergantikan, jika kata yang satu dengan yang lainnya dapat digantikan tetapi maknanya masih sama berarti kedua unsur itu dapat digantikan, (Sudaryanto, 2015).

Adapun pedoman teknik analisis data yaitu (1) mengumpulkan berbagai data-data tentang Habib Rizieq Shihab mengenai Kasus Kerumunan dan RS Ummi Bogor Edisi Mei 2021 yang diperoleh dari media online detiknews.com, (2) data yang telah diperoleh oleh peneliti dijabarkan dari kata perkata, (3) setelah itu data dikelompokkan atau diklasifikasikan berdasarkan kesalahan pada tataran morfologis, (4) selanjutnya yaitu dianalisis sesuai komponen kesalahan , dan (5) terakhir yaitu membuat kesimpulan data, dimana data yang sudah dikelompokkan berdasarkan kesalahan pada tataran morfologis yaitu dibahas kembali untuk mendapatkan kesimpulan dari hasil penelitian atau permasalahan yang ada.

\section{HASIL DAN PEMBAHASAN PENELITIAN}

Proses morfologis yaitu merupakan proses pembentukan kata dimana kata tersebut yang asal mulanya hanya berupa bentuk kata dasar yang mengalami perubahan sehingga menjadi bentuk kata yang baru. Proses ini mencakup afiksasi/pengimbuhan, reduplikasi/pengulangan, dan komposisi/pemajemukan. Dalam proses morfologis, yang menjadi suatu bentuk terkecilnya yaitu dinamakan dengan morfem, sedangkan bentuk terbesarnya yaitu dinamakan dengan kata. Berikut penjabaran data hasil proses morfologis dari kesalahan afiksasi, reduplikasi, dan komposisi. 
3832 Kajian Morfologis pada Pemberitaan Habib Rizieq Shihab Rekomendasinya sebagai Materi Menyusun Teks Berita Di SMP - Mia Solihat, Hendra Setiawan, Ferina Meliasanti

DOI: https://doi.org/10.31004/edukatif.v3i6.1259

\section{Afiksasi}

a. Prefiks

Dalam berita Habib Rizieq Shihab terkait Kasus Kerumunan dan RS.Ummi Bogor dalam Detiknews.com edisi Mei 2021 terdapat tiga kesalahan prefiks yaitu penghilangan prefiks $m e N$-, penghilangan prefiks ber-, dan penghilangan prefiks $d i$ - Berikut adalah analisis data kesalahan penghilangan prefiks $m e N$-, ber-, dan di-.

a) Dua yang jadi catatan adalah, majelis hakim menjelaskan Maulid ini bukan kejahatan sehingga hal-hal tidak patut untuk dijadikan objek suatu tindak pidana.

(D8/BHRS/Detiknews.com/270521)

Kalimat pada data 8 merupakan kesalahan morfologis pada berita Habib Rizieq Shihab terkait Kasus Kerumunan dan RS.Ummi Bogor dalam Detiknews.com edisi Mei 2021 dengan judul Hitungan Pengacara, Habib Rizieq dkk Bebas Juli 2021. Kesalahan tersebut terdapat pada kata jadi. Dimana kesalahan tersebut terjadi karena pada kata jadi tidak berprefiks $m e N$-. Sehingga kata jadi yang mendapatkan prefiks $m e N$ - tentu akan berubah sehingga akan membentuk kata menjadi. Proses pembentukan kata menjadi adalah prefiks meN- + kata dasar jadi.

KBBI V menyatakan bahwa kata jadi memiliki arti yaitu (1) mengambil dampak dengan cepat (selesai, selesai); tidak batal, (2) benar-benar terjadi; datang asli (kemenangan), (3) selesai, (4) lahir; lahir, (5) telah selesai; siap untuk menggunakan, (6) menegaskan pada saat itu; setuju, (7) menjadi, (8) oleh sebab itu; maka; dengan demikian. Sedangkan kata menjadi memiliki arti (1) (diangkat, dipilih) sebagai, (2) (dibuat) untuk, (3) berubah keadaan (wujud, barang) lain; menjelma sebagai, (4) menjabat pekerjaan (sebagai). Jadi kalimat "Dua yang jadi catatan adalah, majelis hakim menjelaskan Maulid ini bukan kejahatan sehingga hal-hal tidak patut untuk dijadikan objek suatu tindak pidana" dalam detiknews.com mengalami kesalahan yaitu penghilangan pada prefiks $m e-N$. Perbaikan untuk kalimat pada penghilangan prefiks $m e N$ adalah "Dua yang menjadi catatan adalah, majelis hakim menjelaskan Maulid ini bukan kejahatan sehingga hal-hal tidak patut untuk dijadikan objek suatu tindak pidana". Kata menjadi dalam kalimat tersebut memiliki arti (1) (diangkat, dipilih) sebagai dan (2) (dibuat) untuk.

b) Jaksa kemudian menolak bertanya kepada empat orang ahli, termasuk Refly Harun. Alasannya, keempat saksi itu tak kompeten dalam kasus ini.

(D4/BHRS/Detiknews.com/190521)

Kalimat pada data 4 merupakan kesalahan morfologis pada berita Habib Rizieq Shihab terkait Kasus Kerumunan dan RS.Ummi Bogor dalam Detiknews.com edisi Mei 2021 dengan judul berita Hakim Periksa Habib Rizieq sebagai Terdakwa Kasus Swab Palsu 27 Mei. Kesalahan tersebut terdapat pada kata kompeten. Hal tersebut terjadi karena kata kompeten tidak berprefiks ber-

Menurut KBBI V menyatakan bahwa kompeten memiliki arti (1) cakap (mengetahui), (2) berkuasa (memutuskan, menentukan) sesuatu; berwewenang. Sedangkan arti kata berkompeten yaitu mempunyai kompetensi. Jadi, kalimat "Jaksa kemudian menolak bertanya kepada empat orang ahli, termasuk Refly Harun. Alasannya, keempat saksi itu tak kompeten dalam kasus ini”" mengalami kesalahan yaitu berupa penghilangan pada prefiks ber-. Perbaikan kalimat penghilangan prefiks ber- adalah "Jaksa kemudian menolak bertanya kepada empat orang ahli, 
3833 Kajian Morfologis pada Pemberitaan Habib Rizieq Shihab Rekomendasinya sebagai Materi Menyusun Teks Berita Di SMP - Mia Solihat, Hendra Setiawan, Ferina Meliasanti

DOI: https://doi.org/10.31004/edukatif.v3i6.1259

termasuk Refly Harun. Alasannya, keempat saksi itu tak berkompeten dalam kasus ini”. Arti kata berkompeten pada kalimat tersebut adalah mempunyai kompetensi atau kekuasaan.

c) Saya penasaran sekali dengan Terdakwa, pertanyaan ini unek-unek saya, mengapa Terdakwa tidak bersabar diri misalnya untuk acara tunda dulu?

(D27/BHRS/Detiknews.com/100521)

Kalimat pada data 27 merupakan kesalahan morfologis pada berita Habib Rizieq Shihab terkait Kasus Kerumunan dan RS.Ummi Bogor dalam Detiknews.com edisi Mei 2021 dengan judul berita Jaksa ke HRS: Kan Banyak Penggemar, Kenapa Tak Tahan Diri?. Kesalahan tersebut terdapat pada kata tunda. Hal tersebut terjadi karena kata tunda tidak berprefiks di-.

Penggunaan kata tunda dalam kalimat tersebut kurang tepat, seharusnya kata tunda dalam kalimat tersebut diubah dengan ditambahkan prefiks di- yaitu menjadi ditunda. Jadi, kalimat "Saya penasaran sekali dengan Terdakwa, pertanyaan ini unek-unek saya, mengapa Terdakwa tidak bersabar diri misalnya untuk acara tunda dulu?" terdapat kesalahan penghilangan prefiks di. Perbaikan kalimat penghilangan prefiks $d i$ - pada data 27 adalah "Saya penasaran sekali dengan Terdakwa, pertanyaan ini unek-unek saya, mengapa Terdakwa tidak bersabar diri misalnya untuk acara ditunda dulu?".

\section{Sufiks}

Dalam berita Habib Rizieq Shihab terkait Kasus Kerumunan dan RS.Ummi Bogor dalam Detiknews.com edisi Mei 2021 terdapat empat kesalahan sufiks yaitu penghilangan sufiks -kan, penghilangan sufiks -an, penghilangan sufik -i-, dan penghilangan sufiks $-n y a$. Berikut adalah analisis data kesalahan penghilangan sufiks -kan, -an, $i-$, dan -nya.

a) Pejabat Humas PN Jakarta Timur, Alex Adam Faisal, menyebut sidang bakal dilanjutkan pada 27 Mei 2021.(D1/BHRS/Detiknews.com/190521)

Kalimat pada data 1 merupakan kesalahan morfologis pada berita Habib Rizieq Shihab terkait Kasus Kerumunan dan RS.Ummi Bogor dalam Detiknews.com edisi Mei 2021 dengan judul berita Hakim Periksa Habib Rizieq sebagai Terdakwa Kasus Swab Palsu 27 Mei. Kesalahan tersebut yaitu terdapat pada kata menyebut dimana kata tersebut tidak bersufiks - kan.

Menurut KBBI V menyatakan bahwa menyebut memiliki arti (1) memungkinkan judul (untuk); mengumumkan judul sesuatu; penamaan, (2) artikulasi nama (benda, individu, dan sebagainya); memanggil nama, (3) verbalisasi (kata-kata dan sebagainya); mengatakan; menyajikan, (4) mengatakan (menceritakan dan sebagainya); mengatakan. Sedangkan arti kata benyebutkan yaitu menyebut (untuk orang lain). Jadi, kalimat "Pejabat Humas PN Jakarta Timur, Alex Adam Faisal, menyebut sidang bakal dilanjutkan pada 27 Mei 2021" mengalami kesalahan terhadap penghilangan pada prefiks ber-. Perbaikan pada kalimat yang mengalami penghilangan pada prefiks ber- adalah "Pejabat Humas PN Jakarta Timur, Alex Adam Faisal, menyebutkan sidang bakal dilanjutkan pada 27 Mei 2021”. Arti kata menyebutkan pada kalimat tersebut adalah menyebut (untuk orang lain) Dua yang jadi catatan adalah, majelis hakim menjelaskan Maulid ini bukan kejahatan sehingga hal-hal tidak patut untuk dijadikan objek suatu tindak pidana.

(D9/BHRS/Detiknews.com/270521) 
Kalimat pada data 9 merupakan kesalahan morfologis pada berita Habib Rizieq Shihab terkait Kasus Kerumunan dan RS.Ummi Bogor dalam Detiknews.com edisi Mei 2021 dengan judul berita Hitungan Pengacara, Habib Rizieq dkk Bebas Juli 2021. Kesalahan tersebut yaitu terdapat pada kata tindak dimana kata tersebut tidak bersufiks -an.

Menurut KBBI V menyatakan bahwa tindak memiliki arti (1) langkah (2) perbuatan. Sedangkan arti kata tindakan yaitu (1) sesuatu yang dilakukan; perbuatan, (2) tindakan yang dilaksanakan untuk mengatasi sesuatu, (3) sanksi pidana yang berbeda dari pemidanaan. Jadi, kalimat "Dua yang jadi catatan adalah, majelis hakim menjelaskan Maulid ini bukan kejahatan sehingga hal-hal tidak patut untuk dijadikan objek suatu tindak pidana" terdapat kesalahan penghilangan sufiks an-. Perbaikan kalimat penghilangan sufiks -an pada data 9 adalah "Dua yang jadi catatan adalah, majelis hakim menjelaskan Maulid ini bukan kejahatan sehingga hal- hal tidak patut untuk dijadikan objek suatu tindakan pidana". Arti kata tindakan pada kalimat tersebut adalah sesuatu yang dilakukan atau perbuatan.

b) Majelis hakim yang terhormat, ada beberapa ahli yang kami kesampingkan. Pertama, ahli Refly Harun, ahli tata negara, yang bersangkutan menyatakan ahli di bidang konstitusi sehingga mengenal perkara ini adalah hukum pidana terapan sehingga kami menyampingkan keterangan ahli.

(D5/BHRS/Detiknews.com/190521)

Kalimat pada data 10 merupakan kesalahan morfologis pada berita Habib Rizieq Shihab terkait Kasus Kerumunan dan RS.Ummi Bogor dalam Detiknews.com edisi Mei 2021 dengan judul berita Hakim Periksa Habib Rizieq sebagai Terdakwa Kasus Swab Palsu 27 Mei. Kesalahan tersebut yaitu terdapat pada kata mengenal dimana kata tersebut tidak bersufiks $-i$.

Menurut KBBI V menyatakan bahwa mengenal memiliki arti (1) mengetahui; kenal (akan); tahu (akan). (2) mempunyai rasa. Sedangkan arti kata mengenali yaitu mengetahui tandatandanya (ciri-cirinya). Jadi, kalimat "Majelis hakim yang terhormat, ada beberapa ahli yang kami kesampingkan. Pertama, ahli Refly Harun, ahli tata negara, yang bersangkutan menyatakan ahli di bidang konstitusi sehingga mengenal perkara ini adalah hukum pidana terapan sehingga kami menyampingkan keterangan ahli" terdapat kesalahan penghilangan sufiks $-i$. Perbaikan kalimat penghilangan sufiks $-i$ pada data 10 adalah "Majelis hakim yang terhormat, ada beberapa ahli yang kami kesampingkan. Pertama, ahli Refly Harun, ahli tata negara, yang bersangkutan menyatakan ahli di bidang konstitusi sehingga mengenali perkara ini adalah hukum pidana terapan sehingga kami menyampingkan keterangan ahli”. Arti kata mengenali pada kalimat tersebut adalah mengetahui tanda-tandanya.

c) Dia mengklaim bila sebelumnya semua tertib dan sesuai prokes.

(D12/BHRS/Detiknews.com/040521)

Kalimat pada data 12 merupakan kesalahan morfologis pada berita Habib Rizieq Shihab terkait Kasus Kerumunan dan RS.Ummi Bogor dalam Detiknews.com edisi Mei 2021 dengan judul berita Pengakuan Mengejutkan Habib Rizieq Langgar Protokol Kesehatan. Kesalahan tersebut yaitu terdapat pada kata sетиа dimana kata tersebut tidak bersufiks -nya.

Menurut KBBI V menyatakan bahwa semиa memiliki arti (1) segala; sekalian, (2) sekaliannya; semuanya, (3) belaka; semata, (4) segenap; seluruh. Sedangkan arti kata semuanya 
3835 Kajian Morfologis pada Pemberitaan Habib Rizieq Shihab Rekomendasinya sebagai Materi Menyusun Teks Berita Di SMP - Mia Solihat, Hendra Setiawan, Ferina Meliasanti

DOI: https://doi.org/10.31004/edukatif.v3i6.1259

yaitu segala-galanya. Jadi, kalimat "Dia mengklaim bila sebelumnya semua tertib dan sesuai prokes" terdapat kesalahan penghilangan sufiks -nya. Perbaikan kalimat penghilangan sufiks nya pada data 12 adalah "Dia mengklaim bila sebelumnya semuanya tertib dan sesuai prokes". Arti kata semuanya pada kalimat tersebut adalah segala-galanya.

\section{Konfiks}

Dalam berita Habib Rizieq Shihab terkait Kasus Kerumunan dan RS.Ummi Bogor dalam Detiknews.com edisi Mei 2021 terdapat kesalahan konfiks yaitu penghilangan konfiks ber-an. Berikut adalah analisis data kesalahan penghilangan sufiks -kan, -an, $i$-, dan -nya.

a. Baik, jadi ahli Refly Harun Saudara tolak karena Anda anggap tidak kompeten begitu ya karena tidak sesuai bidangnya?

(D2/BHRS/Detiknews.com/190521)

Kalimat pada data 2 merupakan kesalahan morfologis pada berita Habib Rizieq Shihab terkait Kasus Kerumunan dan RS.Ummi Bogor dalam Detiknews.com edisi Mei 2021 dengan judul berita Hakim Periksa Habib Rizieq sebagai Terdakwa Kasus Swab Palsu 27 Mei. Kesalahan tersebut terdapat pada kata anggap. Hal tersebut terjadi karena kata anggap tidak berprefiks ber-an.

Menurut KBBI V menyatakan bahwa anggap tidak memiliki arti. Sedangkan arti kata beranggapan yaitu memiliki arti (1) berpendapat, menyangka, (2) bergantian (menari, mempersilakan minum, dan sebagainya). Jadi, kalimat "Baik, jadi ahli Refly Harun Saudara tolak karena Anda anggap tidak kompeten begitu ya karena tidak sesuai bidangnya?" terdapat kesalahan penghilangan prefiks ber-an. Perbaikan kalimat penghilangan prefiks ber-an pada data 2 adalah "Baik, jadi ahli Refly Harun Saudara tolak karena Anda beranggapan tidak kompeten begitu ya karena tidak sesuai bidangnya?". Arti kata beranggapan pada kalimat tersebut adalah berpendapat, menyangka.

\section{Reduplikasi}

a. Pengulangan sebagian (penghilangan kata dasar bentuk komplek)

a) Ya secara tim pengacara dan Habib Rizieq kita masih pikir-pikir (banding) karena kita masih menganggap bahwa yang dilakukan Habib Rizieq dkk adalah bukan suatu kejahatan sehingga tidak patut untuk dikenakan hukuman kurungan badan tetapi secara pribadi saya bersyukur, Alhamdulillah.

(D7/BHRS/Detiknews.com/270521)

Dari kalimat pada data 7 di atas terdapat kesalahan morfologis pada Reduplikasi yaitu pada kata pikir-pikir. Hal tersebut terjadi karena kata pikir-pikir pada kalimat di atas menggunakan pengulangan sebagian tanpa kata dasar bentuk komplek. Kata pikir-pikir kurang tepat dan tidak terdapat dalam kamus KBBI, sedangkan yang terdapat di dalam KBBI yaitu kata berpikir-pikir dimana yang mempunyai arti menimbang-nimbang (baik buruknya, untung ruginya, dan sebagainya). Jadi, kalimat "Ya secara tim pengacara dan Habib Rizieq kita masih pikir-pikir (banding) karena kita masih menganggap bahwa yang dilakukan Habib Rizieq dkk adalah bukan suatu kejahatan sehingga tidak patut untuk dikenakan hukuman kurungan badan tetapi secara pribadi saya bersyukur, Alhamdulillah" terdapat pengulangan sebagian penghilangan kata dasar bentuk komplek. 
3836 Kajian Morfologis pada Pemberitaan Habib Rizieq Shihab Rekomendasinya sebagai Materi Menyusun Teks Berita Di SMP - Mia Solihat, Hendra Setiawan, Ferina Meliasanti

DOI: https://doi.org/10.31004/edukatif.v3i6.1259

Perbaikan kalimat penghilangan kata dasar bentuk komplek pada data 7 yaitu "Ya secara tim pengacara dan Habib Rizieq kita masih berpikir-pikir (banding) karena kita masih menganggap bahwa yang dilakukan Habib Rizieq dkk adalah bukan suatu kejahatan sehingga tidak patut untuk dikenakan hukuman kurungan badan tetapi secara pribadi saya bersyukur, Alhamdulillah". Keterkaitan kata berpikir-pikir pada kalimat di atas yaitu menimbang-nimbang baik buruknya atau untung ruginya.

\section{Pemajemukan}

a. Kata majemuk yang sudah senyawa benar ditulis serangkai

a) Pengakuan ini baru terjadi sebab sebelumnya Rizieq seringkali malah menyerang balik jaksa.

(D3/BHRS/Detiknews.com/040521)

Pada data 3 terdapat kesalahan penulisan proses morfologis kata majemuk atau penggabungan dua kata. Kesalahan yang terdapat pada kalimat tersebut yaitu terdapat pada kata seringkali. Hal tersebut terjadi karena pada kata seringkali dimana cara penulisannya kurang tepat, yang seharusnya ditulis dengan terpisah tetapi ditulis secara serangkai. Menurut Kamus Besar Bahasa Indoensia, penulisan kata seringkali harus ditulis dengan terpisah. Jadi, perbaikan penulisannya yaitu menjadi kata sering kali yang ditulis secara terpisah. Perbaikan kalimat di atas yaitu menjadi "Pengakuan ini baru terjadi sebab sebelumnya Rizieq sering kali malah menyerang balik jaksa".

b. Kata majemuk yang kesenyawaannya agak kurang ditulis terpisah dengan memberikan garis pemisah atau tidak

a) Jaksa mengatakan kedatangan Habib Rizieq ke Megamendung disambut kurang-lebih 3.000 orang.

(D21/BHRS/Detiknews.com/170521)

Pada data 21 terdapat kesalahan penulisan berita dalam proses morfologis pemajemukan atau penggabungan dua kata. Kesalahan pada kalimat di atas terdapat pada kata kurang-lebih. Hal tersebut terjadi karena pada kata kurang-lebih cara penulisannya kurang tepat, seharusnya ditulis secara terpisah tanpa menggunakan garis pemisah atau tanpa tanda hubung. Pada kata kurang-lebih dalam kalimat di atas termasuk ke dalam kesalahan kata majemuk, karena unsur gabungan pada kata tersebut dapat berpasangan dengan morfem lain. Oleh karena itu, perbaikan cara penulisan pada kata kurang-lebih dalam kalimat di atas seharusnya yaitu kurang lebih tanpa menggunakan garis pemisah atau tanpa tanda hubung.

Kesalahan penulisan pada kata kurang-lebih bukan termasuk ke dalam kesalahan reduplikasi atau kata ulang. Karena dalam morfologi bahasa Indonesia, suatu kata dapat disinggung sebagai reduplikasi atau kata ulang apabila kata tersebut diulang dan termasuk bentuk dasar. Sementara itu, apabila jika kita lihat kata kurang-lebih tidak terdapat bentuk pengulangan kata, dan masing-masing dari unsur kata tersebut tidak dapat dijadikan sebagai bentuk dasar kata.

\section{Rekomendasi Penelitian sebagai Materi Ajar Menyusun Teks Berita di SMP}

Hasil dari penelitian ini yaitu akan direkomendasikan kepada guru Bahasa Indonesia berupa bahan ajar tentang materi menyusun teks berita di Sekolah Menengah Pertama (SMP). Materi ajar yang sesuai dengan penelitian ini adalah Kompetensi Dasar (KD) 4.2, yakni menyajikan data dan informasi dalam bentuk berita 
3837 Kajian Morfologis pada Pemberitaan Habib Rizieq Shihab Rekomendasinya sebagai Materi Menyusun Teks Berita Di SMP - Mia Solihat, Hendra Setiawan, Ferina Meliasanti

DOI: https://doi.org/10.31004/edukatif.v3i6.1259

secara lisan dan tulis dengan memperhatikan struktur, kebahasaan, atau aspek lisan (lafal, intonasi, mimik, dan kinesik). Materi ajar ini dapat dijadikan pedoman oleh guru dalam kegiatan pembelajaran tentang kalimat teks berita di SMP semester 1 atau ganjil.

\section{KESIMPULAN}

Berdasarkan hasil penelitian yang telah diteliti oleh penulis dapat disimpulkan bahwa penelitian ini dikaji dengan menggunakan proses morfologis. Yaitu jenis-jenis proses morfologis serta penulisan kata pemajemukan pada pemberitaan Habib Rizieq Shihab dalam media detiknews.com. Proses morfologis yaitu mencakup jenis afiksasi, reduplikasi, dan komposisi. Dimana afiksasi yaitu proses pengimbuhan kata dimana yang awalnya kata tersebut berdiri dengan sendirinya sampai dapat membentuk kata secara komplek sehingga dapat membentuk kata yang baru, serta terdapat proses afiksasi yaitu berupa prefiks, infiks, konfiks, dan sufiks. Selain itu ada reduplikasi, dimana reduplikasi sendiri merupakan proses pengulangan kata baik secara keseluruhan maupun sebagian, baik dengan variasi fonem maupun tidak, yang dapat mengubah bentuk kata dari dasar menjadi bentuk kata yang kompleks sehingga dapat menimbulkan kata yang baru, terdapat jenis reduplikasi juga yaitu pengulangan secara keseluruhan, sebagian, dengan variasi fonem, dan dengan imbuhan. Dan yang terakhir yaitu proses morfologis pemajemukan merupakan proses penggabungan antara kata yang satu dengan yang lainnya, baik penggabungan yang dua bentuk kata dasar atau lebih sehingga kata tersebut dapat menimbulkan arti yang baru, dan terdapat juga penulisan kata pemajemukan yaitu kata majemuk yang sudah senyawa benar ditulis serangkai, serta kata majemuk yang kesenyawaannya agak kurang ditulis terpisah dengan memberikan garis pemisah atau tidak.

Hasil penelitian ini juga direkomendasikan sebagai pembelajaran bahasa Indonesia di SMP guna untuk membantu guru dalam proses pembelajaran dalam pembelajaran menyusun teks berita. Serta untuk menambah wawasan dalam penulisan teks berita terutama dalam proses morfologis yaitu afiksasi, reduplikasi, serta pemajemukan.

\section{DAFTAR PUSTAKA}

Aprilia, O., Qoryah, A. N., \& Aprilia, O. Y. (2020). Analisis Kesalahan Berbahasa Bidang Morfologi Pada Portal Radar Solo Tema Covid-19. Imajeri: Jurnal Pendidikan Bahasa Dan Sastra Indonesia, 3(1), 8292.

Aulia, N., \& Anggraini, N. (2020). Analisis Kesalahan Morfologi Dalam Artikel Pendidikan Surat Kabar Online Di Era New Normal 2020. Jurnal Sasindo Unpam, 8(2), 56-69.

Damayanti, I., \& Nugraheni, A. S. (2020). Analisis Bacaan Berita Kuldesak Lantaran Jerebu Di Majalah Tempo 21-27 September 2015 Pada Buku Ajar Tematik Kelas V Sd/Mi. Bahtera Indonesia; Jurnal Penelitian Bahasa Dan Sastra Indonesia, 5(2), 119-134.

Evitasari, E., \& Nasucha, Y. (2016). Kata Bersufiks Pada Tajuk Rencana Suara Merdeka Dan Implikasinya Terhadap Pembelajaran. Fakultas Keguruan Dan Ilmu Pendidikan.

Isfanti, L., \& Nasucha, Y. (2017). Proses Morfologis Dalam Rubrik Opini Pada Surat Kabar Kompas Edisi Jumat, 26 Desember 2014 Sebagai Pembelajaran Bahasa Indonesia Sma/Smk/Ma Kelas Xii. Universitas Muhammadiyah Surakarta.

Kbbi, V. (2018). Kamus Besar Bahasa Indonesia Edisi Kelima. Aplikasi Luring Resmi Badan Pengembangan Dan Pembinaan Bahasa, Kementrian Pendidikan Dan Kebudayaan Republik Indonesia.

Kridalaksana, H. (2007). Pembentukan Kelas Kata Dalam Bahasa Indonesia. Jakarta: Balai Pustaka. 
3838 Kajian Morfologis pada Pemberitaan Habib Rizieq Shihab Rekomendasinya sebagai Materi Menyusun Teks Berita Di SMP - Mia Solihat, Hendra Setiawan, Ferina Meliasanti

DOI: https://doi.org/10.31004/edukatif.v3i6.1259

Kristi, M. W. P. (2016). Analisis Kesalahan Sintaksis Dan Morfologis Karangan Bahasa Inggris Siswa Sma Bopkri I Yogyakarta. Diksi, 24(1).

Metode, S. (2018). Penelitian Kuantitatif, Kualitatif, Dan R\&D. Alfabeta Bandung.

Oktaviani, E. S., \& Nasucha, Y. (2016). Analisis Kesalahan Morfologis Pada Karangan Deskripsi Siswa Kelas Vii Smp Negeri 1 Kradenan Tahun Ajaran 2015/2016. Universitas Muhammadiyah Surakarta.

Purwanto, R. D. (2016). Analisis Proses Morfologis Pada Kolom Sepak Bola Di Koran Harian Solopos Edisi November 2014.

Rahmah, M. (N.D.). Penggunaan Prefiks Pada Berita Detik. News Di Media Daring Detik. Com Dan Implikasinya Terhadap Pembelajaran Bahasa Dan Sastra Indonesia Kelas Viii Smp.

Rohmadi, M., Nasucha, Y., \& Wahyudi, A. B. (2012). Morfologi: Telaah Morfem Dan Kata. Surakarta: Yuma Pustaka.

Sudaryanto, S. (2015). Metode Dan Aneka Teknik Analisis Bahasa. Yogyakarta: Appti.

Tarigan, G. H. (2013). Menulis Sebagai Suatu Keterampilan Berbahasa, Bandung: Cv. Bandung: Angkasa.

Utami, M. A. P., Muzaqqi, M., Ningrum, S. P. R., \& Ulya, C. (2021). Analisis Kesalahan Morfologi Kata Pada Laman Berita Daring Publikasi Online. Id. Jurnal Skripta, 7(1). 